УДК 636.4.082

(C) 2013

Бірта Г. О., доктор сільськогосподарських наук,

Бургу Ю. Г., кандидат сільськогосподарських наук

Вищий навчальний заклад Укоопспілки «Полтавський університет економіки і торгівлі»

\title{
ФІЗИКО-ХІМІЧНИЙ ТА ЖИРНОКИСЛОТНИЙ СКЛАД САЛА
}

\section{Рецензент - доктор сільськогосподарських наук, професор В. П. Рибалко}

\begin{abstract}
Свиняче сало - високопоживний харчовий продукт, який містить такі незамінні жирні кислоти, як ліноленова та арахідонова, щчо входять до складу ядра клітини і впливають на відтворення потомства. У салі незамінних жирних кислот більше, ніж у коров'ячому маслі. Сало є обов'язковим компонентом не лише для виробництва ковбас, а й для харчування людей важкої фізичної праці як високоенертетичний продукт. Використання у харчуванні 30-50 г свинячого жиру забезпечує добову норму в незамінних поліненасичених жирних кислотах, щуо становить 3-6 грамів. У статті наведено результати експериментальних робіт із вивчення впливу фізико-хімічних властивостей та жирнокислотного складу на якість сала свиней різних порід залежно від вагових кондииій.
\end{abstract}

Ключові слова: ліпіди, жирнокислотний склад, фізико-хімічні показники, свині, порода, вагові кондиції, протеїн, жир, сало.

Постановка проблеми. Свиняче сало - високопоживний харчовий продукт, який містить такі незамінні жирні кислоти, як ліноленова та арахідонова, що входять до складу ядра клітини і впливають на відтворення потомства. У салі незамінних жирних кислот більше, ніж у коров'ячому маслі. Сало $є$ обов'язковим компонентом не лише для виробництва ковбас, а й для харчування людей важкої фізичної праці як високоенергетичний продукт. Використання у харчуванні 30-50 г свинячого жиру забезпечує добову норму в незамінних поліненасичених жирних кислотах, що становить 3-6 грамів.

Жирність свинини визначають віком тварин, породою, системами годівлі та утримання. За інтенсивної відгодівлі ростучих підсвинків, коли живої маси 100 кг вони досягають у 6-місячному віці, м'ясо в тушах становить 50-63\%, тобто залишається нежирним. В останній час різко змінилися вимоги до м'ясопродукції: зростає попит на нежирну свинину і зменшується - на сало.

Такий різкий поворот у вимогах до свинини викликаний покращеним забезпеченням населення різноманітними жирами рослинного та тваринного походження. Тому, збільшуючи виробництво свинини, слід враховувати не лише кількість, але й якість одержаної продукції.

Жирова тканина утворює м'ясо висококалорійне, ніжне, ароматне, але надмірна кількість жиру в свинині (як і в будь-якому іншому м'ясі) призводить до відповідного зменшення вмісту білка й, кінець-кінцем, - до зниження його харчової цінності [1].

Підшкірний жир (шпик) складається 3 9294 \% жиру, 4-4,5 \% води і 1,3-1,5 \% неплавкого залишку. Поживність 1 кг - 37663 кДж. Температура плавлення - 30-40 ${ }^{0} \mathrm{C}$ [3].

У свинині, як і в інших видах м'яса (яловичина, баранина), містяться жирні кислоти, співвідношення яких визначає смак, щільність і колір жиру, прозорість бульйону, інші органолептичні властивості жиру й, головне, - його поживну цінність [2].

Аналіз основних досліджень і публікацій, у яких започатковано розв'язання проблеми. Поряд із м'ясом добрими харчовими та смаковими якостями ціниться й сало. Незважаючи на добру забезпеченість жирами іншого походження, воно не може бути повністю виключеним із харчування людини. Досліди 3 вивчення раціонального харчування людини показали, що поряд із жирами рослинного походження слід широко використовувати тваринні жири, в тому числі й свиняче сало [1].

Складні ефіри свинячого жиру містять у своєму складі (крім насичених жирних кислот) біологічно активні поліненасичені жирні кислоти: лінолеву, ліноленову та арахідонову. Лінолева досить поширена серед кислот рослинного походження, а от ліноленової та арахідонової в рослинах бракує. Лінолева кислота надходить в організм разом із рослинною їжею, входячи до складу жирів рослинного походження; ліноленова ж та арахідонова, очевидно, синтезуються з останньої. Саме ці кислоти і вважаються найбільш біологічно активними, а жири, до складу яких вони входять, - біологічно повноцінними. Дослідами встановлено, що жири, до складу яких входять поліненасичені жирні кислоти, виявляють виняткову біологічну дію на організм тварин [3].

До останнього часу знання про якісний склад ліпідів жирової тканини були обмежені, - жир- 
нокислотний склад їх майже не вивчався. У зоотехнічних дослідженнях обмежувалися лише деякими фізико-хімічними показниками для характеристики жиру. Більш глибоке вивчення різних жирів показало, що фізико-хімічні й технологічні властивості, а також харчова цінність їх залежить від жирнокислотного складу.

Окремі дослідники, вивчаючи жирнокислотний склад тригліцеридів сала свиней, встановили, що жирова тканина на $90 \%$ складається 3 насичених (пальмітинова та стеаринова) й мононенасичених (олеїнова) жирних кислот. Решта (понад $10 \%$ ) припадає на поліненасичені жирні кислоти. Незважаючи на невелику їх кількість у тригліцеридах, вони відіграють надзвичайно важливу роль в організмі.

Лінолева, ліноленова та арахідонова кислоти проявляють виняткову біологічну активність. Вони стимулюють синтез білків та ліпідів, підвищують стійкість організму проти інфекційних захворювань, підтримують активність ферментів, регулюють процеси окислення й виконують інші, не менш важливі функції в організмі. Саме тому зростає інтерес до вивчення жирнокислотного складу жирів рослинного і тваринного походження.

Аналізуючи сучасний стан досліджень із питань вивчення ліпідів тваринного походження та їх сполук [1], відмічають, що відомості про склад ліпідів забійних тварин досить обмежені, а дані щодо вітчизняних видів і порід тварин майже зовсім відсутні.

Мета досліджень - вивчення вікових та породних відмінностей у жирнокислотному складі триліцеридів хребтового сала. Дане питання має важливе практичне значення в свинарстві для встановлення найбільш оптимальних строків забою тварин із метою одержання м'ясо-сальної свинини високої якості.

Методика проведення досліджень. Для виконання даної роботи були сформовані й поставлені на контрольну відгодівлю три породні гру- пи поросят живою масою 27-32 кг миргородської, великої білої порід та ландрас (по 12 голів у кожній). В період контрольної відгодівлі всі підсвинки знаходилися в однакових умовах утримання та годівлі.

М'ясо-сальні якості піддослідних тварин кожної вагової кондиції вивчали за наслідками забою та обвалки правих півтуш.

Для вивчення якості сала, його фізико-хімічних властивостей та жирнокислотного складу відбирали проби хребтового сала на рівні 9-12-го грудних хребців, ретельно відділяючи від м'яса. Оцінка якості продуктів забою проводилася за методиками А. М. Поливоди, Р. В. Стробикіної, М. Д. Любецького [4].

Результати досліджень. У салі свиней даних порід із живою масою 80 кг було значно більше води та протеїну й менше жиру, ніж у свиней цих порід із живою масою 100 та 125 кілограмів. Так, у свиней миргородської породи при забої їх у 80 кг у салі було: $6,79 \%$ води, $1,42 \%$ протеїну та $91,79 \%$ жиру, а у тварин із живою масою 100 кг, відповідно, 5,79; 1,02 та 93,19\%. Аналогічну картину за цими показниками маємо й для інших порід: велика біла - 7,17; 1,68; 91,15 \% та 6,65; 1,$07 ; 92,28 \%$ та ландраси - 7,37; 1,67; $90,96 \%$ i 6,$48 ; 1,12 ; 92,40 \%$.

Хімічний склад сала свиней миргородської, великої білої та ландрас змінюється залежно від вагових кондицій піддослідних тварин (табл. 1).

Таким чином, зі збільшенням живої маси тварин спостерігається закономірне зменшення загальної вологи та протеїну й збільшення вмісту жиру в хребтовому салі.

Аналіз одержаних даних дає можливість з'ясувати і міжпородну різницю за цими показниками. Найменше води і протеїну знаходилося в салі свиней миргородської породи і найбільше - у ландрасів. Велика біла порода, незалежно від вагових кондицій, займала за цими показниками проміжне місце.

\section{1. Хімічний склад хребтового сала свиней різних порід і вагових кондицій, \%}

\begin{tabular}{|c|c|c|c|c|}
\hline \multirow{2}{*}{ Показник } & Вагові кондиції, & \multicolumn{3}{|c|}{ Порода } \\
\cline { 3 - 5 } & кг & миргородська & велика біла & ландрас \\
\hline \multirow{3}{*}{ Вода } & 80 & 6,79 & 7,17 & 7,37 \\
& 100 & 6,23 & 6,40 & 6,77 \\
& 125 & 5,79 & 6,65 & 6,48 \\
\hline \multirow{3}{*}{ Протеїн } & 80 & 1,42 & 1,68 & 1,67 \\
& 100 & 1,13 & 1,53 & 1,42 \\
& 125 & 1,02 & 1,07 & 1,12 \\
\hline \multirow{2}{*}{ Жир } & 80 & 91,79 & 91,15 & 90,96 \\
& 100 & 92,64 & 92,17 & 91,81 \\
& 125 & 93,19 & 92,28 & 92,40 \\
\hline
\end{tabular}


Вірогідна різниця по кількості води в хребтовому салі відмічена лише між ландрасами та миргородською породою. За кількістю протеїну в хребтовому салі свиней різних порід і вагових кондицій достовірної різниці не встановлено.

Все це вказує на те, що між породою, забійною масою тварин і якістю сала існує певний взаємозв'язок. Наші дані узгоджуються з даними вчених, які відмічають, що хімічний склад у певній мірі залежить від вгодованості тварин, їх породи, забійної маси та інших факторів, що впливають на процеси жировідкладення.

Вивчали деякі фізико-хімічні властивості сала, a саме: число омилення, кислотне число, початкову і кінцеву температуру плавлення. Дані показники більш конкретно характеризують якісні сторони хребтового шпику.

Фізико-хімічні властивості сала свиней різних порід залежно від відгодівельних кондицій наведені в таблиці 2.

Число омилення, як показник середньої молекулярної маси тригліцеридів сала, дещо змінюється залежно від відгодівельних кондицій, але дана різниця недостовірна. Не встановлено також вірогідної різниці за даним показником i між породами.

Найбільш високе число омилення жиру було у свиней великої білої породи 3 живою масою перед забоєм 100 кг $(199,167)$ і найнижчим $(184,115)$ - із живою масою 80 кілограмів.

У ландрасів зі збільшенням вагових кондицій число омилення зменшувалося. Кислотне число, що характеризує наявність вільних жирних кислот у салі, також коливається від вагових кондицій.

У салі свиней миргородської породи зі збіль- шенням маси тварин кислотне число також збільшується - 3 0,273 (жива маса 80 кг) до 0,307 (жива маса 125 кг).

У великої білої та ландрас спостерігається тенденція до зменшення кислотного числа.

В салі тварин масою 125 кг усіх порід кислотне число вирівнювалося.

Отже, в салі свиней великої білої породи i ландрас вільних жирних кислот більше, ніж у миргородської.

Йодне число, як побічний показник ненасиченості жиру, зі збільшенням маси тварин змінюється. У свиней миргородської та великої білої порід йодне число залежить від вагових кондицій. У тварин із забійною масою 80 кг йодне число було вищим, аніж у тварин масою 125 кілограмів.

Протягом усього періоду відгодівлі йодне число сала свиней миргородської породи було нижчим, ніж у великої білої та ландрас.

Сало свиней породи ландрас усіх вагових кондицій було більш ненасиченим (йодне число 58,19-59,81).

Достовірної міжпородної різниці по величині йодного числа не вставлено. Зменшення величини йодного числа зі збільшенням вагових кондицій тварин не має суворо закономірного характеру і в різних порід за однакових умов годівлі та утримання проявляється по-різному.

Зі збільшенням вагових кондицій, збільшенням кількості сала в них збільшується і температура його плавлення. Температура плавлення залежить від величини йодного числа. Чим вище йодне число жирів, тим нижча його температура плавлення, тим більше в ньому ненасичених жирних кислот.

2. Фізико-хімічні властивості хребтового сала свиней різних порід і вагових кондицій

\begin{tabular}{|c|c|c|c|c|}
\hline \multirow{2}{*}{ Показник } & Порода & \multicolumn{3}{|c|}{ Маса } \\
\cline { 3 - 5 } & & 80 кг & 100 кг & 125 кг \\
\hline \multirow{2}{*}{ Число омилення } & миргородська велика & 189,767 & 193,878 & 192,393 \\
& біла & 184,113 & 199,167 & 192,425 \\
& ландрас & 197,923 & 195,843 & 189,204 \\
\hline \multirow{2}{*}{ Кислотне число } & миргородська & 0,273 & 0,276 & 0,307 \\
& велика біла & 0,499 & 0,383 & 0,274 \\
& ландрас & 0,436 & 0,652 & 0,363 \\
\hline \multirow{2}{*}{ Йодне число } & миргородська & 0,436 & 54,45 & 52,362 \\
& велика біла & 53,410 & 53,972 & 55,730 \\
Початкова температура & ландрас & 57,519 & 58,457 & 59,457 \\
плавлення, град. & миргородська & 29,7 & 29,8 & 29,44 \\
& велика біла & 29,1 & 25,5 & 29,08 \\
Кінцева температура & ландрас & 28,13 & 27,5 & 27,25 \\
плавлення, град. & миргородська & 45,75 & 44,4 & 45,94 \\
& велика біла & 45,0 & 43,6 & 45,54 \\
\hline
\end{tabular}


У наших дослідженнях встановлено, що лярд свиней миргородської породи мав найнижче йодне число і найвищу температуру плавлення; у ландрасів - йодне число було більш високим, а температура плавлення - низькою.

На основі одержаних даних можна зробити загальний висновок, що фізико-хімічні властивості хребтового сала у великій мірі залежать від вагових кондицій і в меншій - від породи.

Вивчався також жирнокислотний склад хребтового сала свиней вищезгаданих порід. Кількість поліненасичених жирних кислот у складі тригліцеридів хребтового сала свиней різних порід і вагових кондицій у салі зменшується зі збільшенням живої маси свиней. Таке закономірне зниження кількості поліненасичених жирних кислот встановлено для всіх порід, які порівнювалися, і підтверджується результатами математичного аналізу ( $\mathrm{P}>0,999)$.

Встановлена і міжпородна різниця по кількості лінолевої, ліноленової та арахідонової кислот.

Лінолевої кислоти було виявлено більше в салі свиней великої білої породи і менше - у миргородської та ландрас. Наслідки дисперсійного аналізу підтверджують вплив породи на кількість даної кислоти в салі.

Крім того, встановлена математично достовірна різниця між миргородською та великою білою породами $(\mathrm{P}>0,99)$, між великою білою та ландрасами $(\mathrm{P}>0,99)$, що досягли при відгодівлі живої маси 125 кілограмів. У тварин із живою масою 80 та 100 кг різниця помітна, але математично недостовірна.

За кількістю ліноленової кислоти в тригліцеридах лярду слід віднести до кращих велику білу породу свиней. Найменша кількість цієї кислоти відмічена у салі свиней миргородської породи. Встановлена достовірна різниця по кількості даної кислоти в лярді між тваринами великої білої

\section{БІБЛІОГРАФІЯ}

1. Баньковская И. Б., Рак Т. М. Особенности формирования мясо-сальных качеств у свиней разных генотипов / И. Б. Баньковская, Т. М. Рак // Перспективы развития свиноводства : тезисы докл. Междунар. конф. - Гродно, 2003. - С. 47-48.

2. Бузик В. А. Мясо-сальные качества свиней разных весовых категорий : Бюл. научн. работ ВИЖ / В. А. Бузик, М. П. Карт. - 1989. - С. 93.

3. Медведев В. A. Генетические и фенотипичес- та миргородської порід, які досягли живої маси $80(\mathrm{P}>0,99), 100(\mathrm{P}>0,99)$ та 125 кг $(\mathrm{P}>0,999)$. Між великою білою породою та ландрасами ця різниця була значно меншою й достовірна лише для тварин, які досягли живої маси 80 кг $(\mathrm{P}>0,99)$.

За кількістю арахідонової кислоти в тригліцеридах сала знову ж таки на перше місце слід поставити велику білу породу свиней і на останнє миргородську. Між даними породами встановлена математично достовірна різниця по кількості вказаної кислоти в лярді тільки для тварин із живою масою $100(\mathrm{P}>0,95)$ та 125 кг ( $>>0,999)$. Між ландрасами та великою білою породою ця різниця була незначною й математично недостовірною $(\mathrm{P}<0,95)$.

У разі збільшення живої маси свиней на відгодівлі спостерігається тенденція до зменшення кількості найбільш активної арахідонової кислоти в тригліцеридах сала свиней даних порід, що призводить до погіршення харчової цінності сала.

\section{Висновки:}

1. Одержані дані узгоджуються з літературними, і лише по абсолютній кількості лінолевої кислоти в тригліцеридах сала відмічена певна різниця, що, ймовірно, пов'язано зі складом ліпідів раціону й температурним режимом, в якому проводився дослід.

2. Динаміка поліненасичених жирних кислот у салі свиней миргородської, великої білої порід та ландрас добре виражена в залежності від вагових кондицій. Збільшення живої маси тварин веде до закономірного зменшення вмісту ненасичених жирних кислот у тригліцеридах сала.

3. Хімічний склад сала, його фізико-хімічні константи і кількість поліненасичених жирних кислот у ньому знаходяться в певній залежності від породи тварин, їх віку і вагових кондицій.

кие факторы улучшения качества свинины / В. А. Медведев, В.Н.Юрченко // Повышение качества продуктов животноводства. - М. : Колос. -1982 . - С. 140-151.

4. Поливода А. М. Методика оценки качества продуктов убоя свиней / А. М. Поливода, Р. В. Стробыкина, Н. Д. Любецкий // Методика исследований по свиноводству. - Х., 1977.C. $48-56$. 